\title{
O PROCESSO DE CONSTRUÇÃO DA IDENTIDADE DE GÊNERO E \\ TRANSEXUALIDADE: narrativas, trânsitos e diferenças
}

\author{
THE CONSTRUCTION PROCESS OF GENDER IDENTITY AND \\ TRANSEXUALITY: narratives, transits and differences
}

Aparecido Francisco dos Reis ${ }^{1}$

\section{Resumo}

Em uma sociedade que divide seus membros de acordo com o sexo biológico, atribuindo-lhes direitos e deveres diversos sobre essa base, moldando homens e mulheres que se distinguem em comportamento, vestimenta, preferências e qualidades, entre tantos outros elementos, é enriquecedor compreender como se constrói aquela pessoa que desafia a ordem, que afronta as regras que regem a identidade de gênero usando a técnica das histórias de vida, esse artigo pretende discutir os processos pelos quais transexuais pensam sua identidade de gênero por meio dos discursos que elaboram sobre si ao longo de suas trajetórias de vida. Nesse sentido, serão considerados como dados para análise, as falas das mulheres trans sobre o momento em que perceberam que pertenciam a um gênero que não correspondia à simetria sexo-corpo-gênero. Esse momento de descoberta está na história de cada uma, muitas vezes presente na infância e adolescência, quando surge com mais ênfase a diferença em relação aos outros meninos e uma identificação com as meninas, seja pelas brincadeiras

\footnotetext{
1 Possui graduação em ciências sociais pela Universidade Estadual Paulista Julio de Mesquita Filho (1992), mestrado em ciências sociais (Sociologia Politica) pela Universidade Federal de São Carlos (1997) e doutorado em Serviço Social, Trabalho e Sociedade pela Universidade Estadual Paulista Julio de Mesquita Filho (2001). Atualmente é associado III na Universidade Federal de Mato Grosso do Sul. Tem experiência com orientações de PIBIC e mestrado, atuando na área de Sociologia, Antropologia com ênfase em diversidade sexual e sexualidade, principalmente com os seguintes temas: violência, homofobia, cultura e religião.
}

Interfaces da Educ., Paranaíba, v.10, n.28, p. 93 à 116, 2019

ISSN 2177-7691 
e jogos ou ainda, pelo desejo de corpo feminino que se materializa nas vestimentas, nos gestos e no jeito de falar.

Palavras-chave: Gênero. Corpo. Transexualidade.

\section{Abstract}

In a society that divides its members according to biological sex, assigning them diverse rights and duties on this basis, molding men and women who distinguish themselves in behavior, dress, preferences and qualities, among many other elements, it is enriching to understand how if one constructs that person who defies order, who confronts the rules governing gender identity using the technique of life histories, this article intends to discuss the processes by which transsexuals think their gender identity through the discourses they elaborate upon themselves along their life trajectories. In this sense, they will be considered as data for analysis, the statements of trans women about when they realized that they belonged to a gender that did not correspond to the sex-body-gender symmetry. This moment of discovery is in the history of each one, often present in childhood and adolescence, when the difference in relation to the other boys appears more strongly and an identification with the girls, either by the games and games or by the desire of the body feminine that materializes in the clothes, the gestures and the way of speaking.

Words key: gender; body; transsexuality.

\section{Sexo, gênero e corpo: pensando a identidade}

Esse texto parte da ideia que as mulheres trans representam suas identidades como afirmação de sua feminilidade e que a imagem que fazem de si mesmas deve ser reconhecida pelos demais membros da sociedade e pelas instituições sociais num processo de afirmação e negação identitária, já que transitam por diferentes interações sociais ao longo de suas vidas, que nomeiam e atribuem significados baseados na lógica da coerência corpo/sexo/gênero. 
Para Hall (2014), questão da identidade surge na modernidade como uma construção discursiva produzida em âmbitos históricos e institucionais específicos mediante estratégias enunciativas. Há uma noção de identidade produzida de acordo com cada época. Assim, a discussão sobre a identidade funciona como um enlace entre as noções de sujeito e as práticas discursivas; esta possui condições determinadas de existência, que incluem os recursos materiais e simbólicos para sustentar sua condicionalidade e sua contingência. (HALL, 2014, p. 13)

Em outras palavras, a identidade é um ponto de sutura entre as práticas e os discursos que interpelam os processos criadores de subjetividade; quer dizer, entre os discursos e práticas que podem ser espaços de questionamento, consentimento ou frustração, que colocam os sujeitos em um determinado lugar, que produzem subjetividades e que constroem sujeitos suscetiveis de se nomear. Seguindo essa linha de pensamento, a construção da identidade implica na possibilidade de recriar algo que se pretendia diferente a princípio.

A identidade é o cenário de confrontação em que o poder se evidencia quando a luta pela identidade se confronta com uma estrutura dominante e homogeneizante que não respeita a diversidade e que reconhece a existência da transexualidade apenas em sua condição subalterna. Desse modo, as mulheres trans constroem sua identidade de gênero em condições não definidas por elas, esta construção se remete a uma experiência conformada por códigos de inteligibilidade a partir dos quais se experimenta o mundo. Pode-se dizer que em última instância, a identidade é envolta pela história e o lugar do subalterno ${ }^{2}$ se apresenta como uma história e uma experiência de opressão que privilegia modelos particulares como as figuras apropriadas da identidade. (GROSSBERG, 1996, p. 157)

\footnotetext{
${ }^{2}$ Segundo Facioli e Miskolci (2015), o debate sobre subalternidade aparece na introdução à obra teórica de Spivak como sendo diferente da ideia de marginalização e marcando, ao contrário, as "camadas mais baixas constituídas por modos específicos de exclusão dos mercados, da representação política legal e da possibilidade de se tornarem membros plenos do Estado dominante".
} 
Nesta situação, os grupos sociais subalternos podem negar-se ou avergonhar-se de si mesmos, como consequência da interiorização de uma imagem deteriorada que se transmite e que produz o ocultamento ou a eliminação dos traços que evidenciam as diferenças.

Usando a palavra diferença como empregado por DERRIDÁ3 ${ }^{3}$ o subalterno é constitutivo do termo dominante e necessário para este. Não existe dominante sem subalterno, assim, a identidade dominante incorpora sua negação. A identidade necessita da diferença, quer dizer, do trabalho discursivo para a elaboração das fronteiras simbólicas.

A identidade ao atuar através da diferença marca limites simbólicos e produz "efeitos de fronteira" (HALL, 2014, p. 16). A identidade para consolidar o processo necessita do exterior constitutivo (HALL, 2014), portanto, diferença e identidade são duas faces da mesma moeda e ambas são efeitos do poder.

Não obstante, o subalterno possui também agência que tem a ver com a transgressão. Uma das formas de transgressão é justamente, a transgeneridade. Aqui se percebe claramente que a transgeneridade transgride a norma de construção das identidades sexuais e de gênero definidas, assim como, as posições e a hierarquia dos corpos sexuados.

Desde o nascimento, essas mulheres foram socializadas de acordo com construções sociais erigidas sobre o seu sexo biológico que distinguem comportamento, direitos e deveres de acordo com o sexo masculino ou feminino (SCOTT, 1998). As escolhas de cores e roupas, brinquedos, a divisão de tarefas domésticas, a posição na hierarquia familiar e da sociedade como um todo; o grau de liberdade sexual, entre tantos outros aspectos da vida cotidiana de mulheres e homens são diretamente afetados

\footnotetext{
${ }^{3} \mathrm{~A}$ palavra Differance em Derridá, se diferencia da palavra Différence (diferença) ao mudar o "e" por "a", que alude a diferir. Se trata de um jogo de palavra entre diferir e diferenciar. Segundo Derridá "não é uma palavra, nem um conceito", é algo que não se pode simbolizar porque transborda a representação, seu significado completo e sempre proposto; nunca é. Esta palavra foi introduzida por Derridá na conferência realizada na Sociedade Francesa de Filosofia, em 27 de janeiro de 1968, publicada no Buletin de La Societé Française de Philosophie (julhosetembro, 1968).
} 
por tais construções sociais que the ditam o que lhe é lícito e ilícito, apropriado e inapropriado, descente e indecente, sendo ele do sexo masculino ou do sexo feminino. A categoria gênero aqui utilizada se refere ao discurso sobre a diferença dos sexos. Essa concepção se remete as ideias, mas também a instituições, estruturas, práticas cotidianas e aos rituais, ou seja, a tudo aquilo que constitui as relações sociais (SCOTT, 1998, p. 15)

Para Scott discurso é um instrumento de organização do mundo, mesmo se ele não é anterior à organização social da diferença sexual, produzindo sentido desta realidade. A diferença sexual não é a causa originária a partir da qual a organização social poderia ter derivado; ela é mais uma estrutura social movediça que deve ser ela mesma analisada em seus diferentes contextos históricos (SCOTT 1998, p. 15).

Para a referida autora, a partir dessa lógica binária, as construções sociais constituem os papéis de gênero, aos quais se entende como identidades calcadas em percepções funcionais e hierárquicas das diferenças sexuais (SCOTT, 1998).

Butler, em sua obra Problemas de gênero: feminismo e subversão da identidade (2010) publicada originalmente em 1990 pergunta se o "sexo" teria uma história ou se é uma estrutura dada, isenta de questionamentos em vista de sua indiscutivel materialidade. Butler discorda da ideia de que só poderíamos fazer teoria social sobre o gênero, enquanto o sexo pertenceria ao corpo e à natureza.

Butler faz uma história sobre o corpo e o sexo, dissolvendo a dicotomia sexo e gênero, enquanto possibilidades limitadas de problematização da natureza biológica de homens e de mulheres. Para Butler, a "ordem compulsória” que exige a coerência total entre um sexo, um gênero, corpo e desejo, são obrigatoriamente heterossexuais. Assim, o conceito de gênero vigente legitima essa ordem, na medida em que seria um instrumento expresso principalmente pela cultura e pelo discurso que inscreve o sexo e as diferenças sexuais fora do campo do social, isto é, o gênero aprisiona o sexo em uma natureza inalcançável à crítica e a desconstrução. 
A inscrição do gênero nos corpos sempre receberá as marcas da cultura, que fornecerão categorias e rótulos distintos para enquadrar as experiências sexuais e afetivas do sujeito. As possibilidades de "ser" ou "viver" a sexualidade- entendida aqui como forma de expressar os prazeres e desejos- também serão estabelecidos socialmente. Daí pode-se inferir que as identidades de gênero e sexuais são políticas, adquirindo sentido pelas redes de poder.

O corpo será o representante máximo na referência a identidade, como sendo algo inequívoco, evidente por si e suas "marcas" biológicas, no entanto, este processo pode acabar se mostrando equivocado e contraditório. Na busca de "fixar" uma identidade aparentemente "natural" e duradoura da sexualidade e do gênero, um modelo unívoco para todos os sujeitos, o destino inexorável e compulsório, apresenta-se a heterossexualidade. Como expressa Louro, "a coerência e a continuidade suposta entre sexo-gênerosexualidade servem para sustentar a normatização da vida dos individuos e das sociedades" (LOURO, 2004, p. 88). Existindo uma norma que regulamenta os gêneros e definindo também uma forma normal de família, sustentada na reprodução sexual e na heterossexualidade, Louro acredita que essa premissa tem um caráter político que organiza a realidade, excluindo mulheres e homens que perturbem essa realidade ou dela escapem.

Assim, as normas regulatórias do sexo têm, portanto, caráter performativo, isto é, têm poder continuado e repetido de produzir aquilo que nomeiam, ressaltando que o corpo se produz principalmente pela linguagem usada para referi-lo, linguagem essa que não faz apenas uma constatação ou uma descrição desses corpos, mas, no instante mesmo da nomeação, constrói, 'faz' aquilo que nomeia. Louro, junto com Butler, sugerem que a linguagem "produz os corpos e os sujeitos" (LOURO, 2004, p. 44). É preciso nomeá-lo e descrevê-lo como, simultaneamente, pertencente a um sexo e pertencendo um sexo para

que o corpo seja compreendido no domínio do humano. Descrever e nomear os gêneros são também modos de fabricá-los e de legitimá-los. 
A categoria primeira de "sexo" já é por si mesma normativa. "As normas regulatórias do 'sexo' trabalham de uma forma performativa para constituir a materialidade dos corpos e, mais especificamente, para materializar o sexo do corpo" (BUTLER, 2007, p. 154). As diferenças são construídas no momento mesmo da nomeação dos corpos. "O 'sexo' é, pois uma das normas pelas quais o 'alguém' simplesmente se torna 'viável', é aquilo que qualifica um corpo para a vida no interior do dominio da inteligibilidade cultural” (idem p. 155). A identificação do sexo permite que o corpo seja a base material sobre a qual um sujeito generificado legível e inteligivel se constituirá. "Nós vemos isto mais claramente nos exemplos daqueles seres abjetos que não parecem apropriadamente generificados; é a sua própria humanidade que se vê questionada” (idem, p. 161).

Nesse contexto, tem-se o banimento da transexualidade enquanto categoria discursiva legítima passivel de se tornar sujeito político, com capacidade para agenciar sua própria identidade de gênero, seu corpo e seu sexo. A heteronormatividade, a imposição social do alinhamento entre o sexo biológico, identidade de gênero, orientação sexual e papel de gênero (JENKINS, 2008), não admitem a desconexão entre corpo/sexo biológico e identidade de gênero nas pessoas trans. Qualquer arranjo dessas categorias na qual, uma delas seja substituida por aquelas vistas como atadas ao sexo oposto é fortemente recriminada não somente por estar em desacordo com as crenças da maioria, mas por ser também entendidas como uma ameaça a reprodução da sociedade (RUBIN, 2012).

As construções das feminilidades e das masculinidades, sempre levadas a efeito a partir da nomeação do corpo ou como mulher ou como homem (nunca como mulher e homem e não-binária), seriam um conjunto de atitudes, ações, comportamentos que se repetem ao longo de um determinado período histórico obedecendo a orientações construídas e sancionadas culturalmente que dizem como um corpo deve (com)portar-se para ser considerado homem - masculino - ou mulher - feminina, além da própria estilização do corpo, através de gestos, movimentos e representações, fornecendo a ilusão de uma masculinidade ou feminilidade essenciais, 
negando a materialização do sexo no corpo e a produção dos gêneros como viabilidade política e cultural.

A questão da transexualidade aparece no ocidente no século XIX, quando a categoria homossexual é estabelecida (FOUCAULT, 1984). Um eixo central na definição de homossexual foi a sua associação com a inversão de gênero: considerou-se que sua "anomalia" não era seu objeto de desejo (uma pessoa do mesmo sexo), mas o fato de desejar de uma posição "invertida" ( uma mulher que deseja como homem e vice-versa no caso do homem homossexual). Assim, a homossexualidade foi entendida como uma espécie de "androginia interna, de hermafroditismo da alma" (FOUCAULT, 1984: 5758). Nos círculos médicos, a distinção entre atração do mesmo sexo e inversão de gênero começou a ocorrer no final do século XIX, quando, a categoria clinica transvestica foi inventada. Havelock Ellis e Magnus Hirschfeld lideram a campanha para estabelecer transvestismo e homossexualidade como categorias separadas (LLAMAS, 1998). Eles argumentam que ser atraído por pessoas do mesmo sexo não está necessariamente associado com a travestilidade, carinho e sensação do gênero oposto (KING, 1998).

Contudo, a distinção entre pessoas com comportamentos específicos para fins sexuais e aquelas que se identificam permanentemente com o gênero oposto e querem mudar suas características corporais, sexuais e de gênero ocorreu na década de 1950, quando o conceito de transexual aparece cunhado por David Cauldwell e popularizado por Harry Benjamin (LLAMAS, 1998). A palavra transexual refere-se a essa pessoa que sente o gênero oposto e quer modificar seu corpo cirurgicamente para parecer com pessoas do gênero oposto (KING, 1998).

No entanto, a literatura médica sobre a transexualidade a coloca na lista de patologias identificadas nas sexualidades consideradas desviantes. Segundo Bento (2006), a posição presente na literatura oficial sobre o assunto, é a de que os/as transexuais e travestis são "transtornados". Bento entende essa concepção como "uma ficção e desconstruí-la significa dar voz aos sujeitos que vivem a experiência e que, em última instância, foram os 
grandes silenciados" (p. 26). Nesse sentido, este texto fará uma discussão acerca das narrativas das mulheres trans em torno de suas identidades em processo e suas passagens de descobertas.

\section{As aproximações}

O trabalho de campo para o projeto foi desenvolvido entre os meses de outubro de 2015 e Maio de 2017, na cidade de Campo Grande como um desenho biográfico-narrativo dessas mulheres realizado por elas e pelos pesquisadores.

Não foi difícil fazer contato com as 9 mulheres trans que concordaram em contar suasvidas, principalmente em razão dos pesquisadores conhecerem as lideranças trans da cidade, e depois elas mesmas indicaram outros nomes. Essa aproximação já vem ocorrendo ao longo de uma década de parceria entre o grupo de pesquisa ${ }^{4}$, do qual participam os pesquisadores e a Associação das Travestis e Transexuais de Mato Grosso do Sul (ATMS). Essas parcerias se traduzem em cursos de capacitação de lideranças, participação em eventos da ATMS, reuniões políticas de definição de demandas e participação de lideranças do movimento trans em seminários na Universidade Federal de Mato Grosso do Sul. Todas se dispuseram a falar sem muitos problemas e na sua maior parte, prefiriram falar na sede da Associação das Travestis e Transexuais de Mato Grosso do Sul (ATMS) em Campo Grande. Somente um depoimento foi realizado no bar Bola 7, no bairro Amambaí, bem próximo da ATMS. Esse último depoimento foi tomado logo após uma reunião política com uma candidata a vereadora nas eleições de 2016. No encontro, as trans e outros membros da comunidade LGBT (Lésbicas, Gays, Bissexuais, Travestis e Transexuais) discutiam o apoio e o voto a determinados candidatos que defendessem a pauta do movimento. Cada entrevista tem aproximadamente duas (2) horas ou mais de duração. As entrevistas em geral, eram histórias

\footnotetext{
${ }^{4}$ Laboratório de Estudos da Violência, Gênero e Sexualidade (LEVS/UFMS). O grupo existe desde 2004 com sede na UFMS, mas com participação ativa nos eventos da comunidade LGBT, tais como: Parada da diversidade, capacitação de DST/Aids, simpósios, audiências públicas entre outras ações.
} 
estimulantes sobre infância, adolescência, família, escola, o estágio de transição, casais, trabalho, hormonização, cirurgia de transgenitalização, o que permitiu uma jornada narrativa para a vida de cada um delas até o momento atual. Todavia neste artigo, serão discutidos apenas as falas referentes a problemática da identidade de gênero, nas quais elas narram os momentos da descoberta e das redefinições de gênero, outros momentos das entrevistas, serão discutidos em outros trabalhos. A maioria das informantes são da cidade de Campo Grande, uma de Corumbá - MS e uma de Nova Alvorada do Sul - MS. Mas todas moram atualmente na capital. Normalmente vem de setores sociais de baixa renda ou da classe média, trabalhavam na ocasião como cabeleleiras (2), empregada do setor privado (1), dona de pensão (1) atentedente em Organização Não-governamental (3) e trabalhadora sexual (2). Entretanto, todas ao longo de suas vidas, em algum momento, exerceram a função de trabalhadoras sexuais.

A técnica utilizada para as entrevistas foi a história da vida procurando criar um desenho qualitativo da narrativa biográfica dando a conhecer e explicar várias situações e ou condições de vida que, com outras técnicas, seriam insuficientes, como: mudanças sociais, períodos de crise, modos de vida alternativos ou não tradicionais.

Segundo BOSI (1995), a abordagem biográfica é útil quando é difícil oferecer interpretações globais. Esse retorno ao indivíduo como unidade de análise é importante por duas razões principais: a) conhecer através dos processos individuais, os desenvolvimentos coletivos e b) conhecer as diferentes facetas da vida cotidiana de um indivíduo; já que permite estabelecer a relação entre ele e a sociedade em que atua, dando voz aos atores que geralmente não são protagonistas da história (BARBIERI 1995). $\mathrm{Na}$ história da vida, então, o social se manifesta, o que chamamos de representações sociais se expressam por meio das vozes dos sujeitos. É uma apropriação do social através da subjetividade. Através da memória, o que é vivido, é atualizado e os episódios narrados adquirem novos significados (BARBIERI 1995). 
Os nomes das colaboradoras dessa pesquisa serão mantidos em sigilo, sendo usados nomes fictícios, embora todas dissessem que não haveria problema no uso do nome pelos quais são conhecidas.Oito (8) delas estão na faixa etária de 25 a 35 anos e uma (1) por volta dos 50 anos.

\section{As narrativas}

A primeira coisa que se observa ao analisar as histórias de vida é que a sensação de estar diferente acompanha as mulheres trans desde infância. Ser diferente significa olhar no espelho e verificar que a norma - a coincidência entre sexo biológico e gênero - não aparece. Desta forma, a identidade de gênero representa o lugar da diferença ou uma multiplicidade de possiveis diferenças. A diferença se manifesta como um enigma, tanto para a pessoa em si, quanto para aqueles que se algum modo se relacionam com o universo dessas mulheres, no caso aqui, Natacha relata um trecho de uma conversa com a sua mãe:

\footnotetext{
Ela me fez perguntas, se eu me sentia normal, porque ela me perguntou como se sente?. Ela me disse"meu filho, eu vejo você de forma diferente". Eu disse a ela, não mãe, é assim que eu sou, acaso sou um monstro?. Talvez eu seja um show ou uma outra coisa qualquer. Ela me perguntou, como você se sente. Normal, eu disse, mas o que é normal para você, ? ela falou. Normal, eu disse. Como você quer que eu me sinta? Estamos investidos do que temos que ser... só isso. (Natacha)
}

Embora as mulheres trans não distingam, ainda na infância o que se passa com elas, percebem que vivem num corpo que de algum modo, os sentidos, a repetida ratificação da diferença, a incompatibilidade nas interações sociais, ou seja o modo como é representada pelos demais, é diferente. Desta forma, a constituição do esquema corporal lhe é dada a partir da diferença e não da semelhança com os demais sujeitos masculinos de sua sociedade e de sua idade. Por exemplo, na história de Natacha, ela se sente normal. Pode-se interpretar a palavra normal como um sentimento de 
estar confortável consigo mesma. Ou seja, do ponto de vista dela, não há nada de errado com seu corpo e com seu comportamento. No entanto, a diferença se torna evidente pelas palavras de sua mãe. Na história é a mãe quem a faz duvidar do que ela é. Natacha se sente normal, mas sua mãe a vê de forma diferente e que a faz a se perguntar o que sou eu? Tal como observou Bento (2006) com essa dúvida, surge uma nova responsabilidade: explicar aos outros o que elas são. A autora afirma que são os discursos sociais, os enunciados da família e aqueles que ocupam o primeiro lugar e limitam as margens do grupo social, são os que definem quem é quem e quais características cada um deve ter.

A família transmite e reafirma os estereótipos de gênero: o que deve ser masculino e o que deve ser feminino, e o que se estabelece como um comportamento adequado de uma criança com essa rotulagem de gênero. Assim a dúvida sobre a sua identidade sempre vem acompanhada de vergonha, estigma e dissimulação, que dão origem a uma luta interna durante a infância, adolescência e até mesmo juventude. Tudo isso se reflete na história de Natacha, como ela mesma realça: "Somos diferentes, ou como dizia antigamente, somos invertidos".

A história de Carla, abaixo, ilustra como o sentimento da diferença se expressa desde a infância na maneira de andar, nos gestos e na forma de conversar. Uma forte associação entre feminilidade e delicadeza está presente no discurso; e essa delicadeza pode ser a chave para definir a feminilidade emergente. Quando se fala em diferença, o padrão esperado de coincidência entre sexo ao nascer e gênero expresso evideciam que ela não é igual aos meninos a não atende as expectativas sociais em torno do papel masculino generificado. A confirmação de ser diferente é unânime, embora nessa idade não seja bem compreendida.

Nessa idade já percebi, porque na escola eu fingia, mas na rua, em casa ... Na rua, especialmente, na maneira de andar, eu hoje vejo como muitos meninos andam. Ojeito que você anda, os gestos, especialmente quando você fala é delicado. Nós somos, eu sempre fui 
bastante delicada e meu pai não gostava disso e por isso que ele me batia muito. (Carla)

Enquanto diferente, é necessário fingir na frente dos demais. Finge ser o que os outros esperam; finge porque sente que algo não está certo, mas ainda não consegue entender porque tem que fingir Isso demonstra um discurso que adere fortemente aos discursos hegemônicos sobre a diferença sexual e a diferença de gênero. A frase de Cristhiane "fingindo não ser homossexual", ainda criança ilustra essa confusão genérica, em que a palavra homossexual é usada para se referir a um homem diferente. Embora tenham nascidos com o sexo masculino, algumas colaboradoras, como Cristhiane se auto identificaram num primeiro momento de suas vidas como meninos homossexuais porque se sentiam diferentes dos outros homens e também era o termo mais socialmente reconhecivel; mas como uma mulher ela recorda desses acontecimentos como um tivesse sido experiências de menina:

Claro, boas lembranças, eu estava com meus pais, fingindo não ser homossexual, ou uma menina. Desde que eu tinha 10 anos, eu senti, mas eu estava com medo de dizer isso para qualquer pessoa e a mim mesmo. Medo, temer mais do que tudo para dizer não? Porque eu estava fingindo, estava fingindo minha homossexualidade. De repente, eu queria me vestir de mulher, é claro, mas secretamente. Mas comos amigos eu fingia que gostava de ficar com eles, mas eu queria mesmo era me juntar às mulheres. Eu ficava com vergonha, com medo. Eu não saí, não foi só da escola, da escola, casa e da minha casa. Fui andar no pasto para ver o gado pastar à tarde e assim por diante, morava na fazenda na época. Eu costumava me sentir como se fosse a única no mundo. Eu senti como se fosse apenas eu. As vezes eu me sential mal, sozinho, oh de repente eu sou o único que é assim! Embora eu tenha um primo que também é assim, ele não morava perto, nem cheguei a conhece-lo, meus pais diziam que ele era assim, morava em outro estado. Eu nunca cheguei a conhecê-lo. (Cristhiane) 
Desta forma, o conjunto de relações e mandatos sociais são internalizados e incorporados. Ao fingir, comportamentos estão sendo internalizados, uma certa disciplina que determina como as mulheres trans devem se relacionar com seu ambiente. Cristhiane vem do setor rural de Mato Grosso do Sul, vivendo hoje em Campo Grande. Provavelmente isto significa que representa uma dificuldade maior para que entenda o que acontecia com ela na infância, como ela mesma expressa, isso a fez sentir-se como a única pesssoa que era assim. E assim, sozinha, sem referências de outras trans e ausência de alguém com quem pudesse conversar e expressar seus sentimentos, Cristihiane ainda lembra que se sentia como um "ser anormal". Além do fato de ser identificada no seu universo de infância por palavras de conotações negativas como maricas, viado, baitola e tantos outros. Esses termos demonstram ainda que essa diferença em relação aos iguais não era correta e fez com que ela sentisse vergonha e medo de ser descoberta. Apesar da feminilidade nascente, essas mulheres na sua infância e adolescência vivem seu gênero de maneira secreta, é também nesses atitudes de se vestirem com roupas e calçados feminos, geralmente das mães e irmãs, que experimentam ser mulheres, normalmente, tendo como referências, as mulheres de seu próprio grupos familiar.

É importande dizer ainda que existiu um trânsito do gênero masculino para o feminino. De acordo com os relatos, esse trânsito muitas vezes foi confuso, tanto no aspecto da conduta, quanto ainda no discurso que elaboram sobre si mesmas, como por exemplo no momento da nomeação que reflete sua passagem entre o homossexual e a garota que elas sentem que são. Essa situação é embaraçosa para elas; isso também se manifesta numa linguagem mais borrada como no relato de Marissa:

Olha, no início eu achava que era gay, por volta dos 5 anos eu pensava assim, mas eu me vestia escondido com as roupas da minha avó. Fiquei assim por muito tempo, sendo gay, mas por dentro eu sabia que era diferente de todo mundo. Era diferente do gay, das gays que eu conhecia na minha cidade que é pequena. Eu sabia que tinha gay. Ai eu vim pra Campo Grande, aqui eu vi travestis, mas eu 
já sabia que existia, as pessoas falavam, às vezes tinha na televisão e eu também via pela internet, quando podia, porque a gente era pobre e não tinha muito acesso. Então, acho que sou travesti agora, as minhas colegas aqui da associação e na rua pro clientes, eu sou travesti. Mas também sei que sou mulher, mas não quero fazer cirurgia...ainda não decidi se vou tomar hormônio, até já fui la na Hospital Universitário ver isso. (Marissa)

A experimentação de diferença e as transformações subseqüentes do corpo permitem que as mulheres trans implantem formas gramaticais masculinas e femininas na construção de seus significados de gênero. Podese afirmar que elas encontram até mesmo o uso de formas masculinas em suas práticas discursivas. Desta forma, paralelamente à mudança corporal, articulam sistemas designificados que as produzem como mulheres trans. Assim, na infância as relações familiares impuseram uma linguagem predominantemente masculina, mas quando se fala do trabalho sexual e da relação com os homens, a linguagem é predominantemente feminina.

$\mathrm{Na}$ história de Alexia, sentindo-se estranha e diferente, Alexia vê de uma maneira diferente seus colegas de escola. Uma feminilidade emergente, é revelada na história de atração e desejo de contato com outras crianças que fossem iguais a ela, com gostos, gestos que eram interpretadas como femininas, no entando, sua experiência escolar foi justamente, numa escola para meninos. Alexia pensava em brincar de boneca e outras brincadeiras femininas e a consequentemente rejeitava os jogos masculinos por serem rústicos (referindo-se ao futebol), que contradizem com sua delicadeza.

Aos sete, oito anos; quando eu estava indo para a escola, certo? eu senti que era diferente para as outras crianças. Eu estudei em uma escola de meninos, uma escola salesiana. Então havia garotos puros, então eu me senti estranho porque eu via os colegas de classe de forma diferente, e além disso, eu ficava muito quieto e depois eu gostava das bonecas, das brincadeiras das menininhas.Sempre nas brincadeiras de grupo eu gostava de fazer o papel de uma mulher porque na escola eu, gente tinha que ser como se fôssemos puramente machos, sempre às vezes você tinha que fazer o papel de 
pequena mulher e eu adorava fazer esses papéis. E dos sete, oito anos assim. Eu já percebi que eu era diferente dos outros. Percebi quando era criança. Eu, porque, eu vi por exemplo que eu não gostava de brincar com os rapazes do jardim, quando eu era pequena. Lá com cerca de cinco ou seis anos. Mas eu ainda eramuito criança. Quando eu estava na escola. Com dez, onze anos eu percebi que era diferente, era delicado então eu não gostava das brincadeiras rudes. Porque era bom estar com as mulheres é que os meninos gostam de jogos mais violentos, é o que eles fazem, certo? Eu não gostava. (Alexia)

Embora elas tenham percebido ou sabida que algo o estava lá antes mesmo de tomar consciência do que venha a ser a transexualidade, o que fica claro nos relatos é que a identidade do gênero não é uma essencialidade. Esta adquire visibilidade nas atitudes, mas principalmente por meio da linguagem e da corporeidade que darão vida à identidade de gênero das mulheres trans.

Isso pode ser visto na história de Rafaela. Sentindo-se identificada com crianças do gênero feminino, pensava sentir-se como uma menina, mesmo que as marcas de gênero presentes em seu corpo fossem masculinas. São os sentimentos de atração pela vida das meninas, suas roupas, brinquedos e sentimentos que validam através do relato o que ela sentia naquele momento: "se sinto inveja de outra garota, é porque eu sou uma garota" diz Rafaela.

Nesta história, como em outras, sentir-se menina é percebido como algo inato, natural, como parte do instinto feminino, como dizem, expressa o sentido de algo que não pode ser reprimido, nem se conter e que não requer maior iluminação:

Desde que eu era uma garotinha, eu me lembro, eu me lembro do jardim, do jardim de infância, eu lembro disso. Naquela época era um jardim, lembro que as crianças me chamaram a atenção. Eu me senti uma garota. Mas desde muito, de muito pequena. Me sentia diferente, certo? Eu me senti como uma garota, embora eu ainda não tenha marcado, eu me lembro as crianças ainda vêem as diferenças, certo? Não todas perceberam isso. Mas eu lembro que havia uma 
garotinha e que todos os pequeninos queriam ficar com aquela garotinha, e isso pra mim, dava raiva, lembro-me, da garotinha. Eu lembro disso, são as coisas que me marcou, um pouco me dá a noção de validar o que eu senti, porque são memórias de menina e eu não consigo pensar se estava lá fora. Mas lembro que gostei delas as da crianças. Eu lembro que havia um menino que me beijava, no jardim havia um túnel e lá ele me beijou e ele tinha 4 anos de idade. Que eu simplesmente queria ser mulher.Isso era o que eu era e não entendia mais, queria ser mulher e não entendia nada além disso. (Rafaela)

No relato de Carine, o futebol, atividade lúdica sempre presente na infância e adolescência dos meninos era rejeitado por ela. Além disso, contrasta com jogos de meninas e o vôlei é visto por Carine como um esporte estritamente feminino. Segundo ela, era como se o masculino não estivesse presente em seu corpo; como se o corpo estivesse vazio do gênero para ser preenchido por outro. Como se fosse um erro da natureza e não jogar futebol na infância era se afirmar como mulher:

Eu nunca joguei, tenho isso até hoje em minha memória, nunca joguei futebol. Não me atraia, não gostava e quando o professor de educação física mandava os meninos jogarem futebol, eu me escondia no banheiro e não saia.

As suas irmãs são suas primeiras referências na infância:

Minha irmã mais velha é muito feminina. E eu mergulhei nisso, isto é, me adaptei ao seu estilo, copiava, porque ela era muito feminina e eu queria ser assim. Ela notou que eu gostava de ser como ela. A minha mãe, às vezes mães, até os pais perceberem que seus filhos têm uma orientação, vamos para dizer, mais desviante, mais feminino, o masculino já não existe já era. Eu sempre brinquei com minhas amigas, eu joguei vôlei com minhas vizinhas, também com minhas colegas na escola. Também brincava de boneca com elas, aquelas brincadeiras com xícaras, fazer comidinha, mas nunca jogava pelada (futebol). Nunca me chamou atenção porque, eu não sei ... não sei, de 
repente eu tive esse instinto feminino, certo? E eu vivi assim. brincar com bonecas, ou assistir, jogar vôlei com parceiras do sexo feminino. Eu via que os meus movimentos eram desde criança bastante efeminados. (Carine).

$\mathrm{Na}$ adolescência, elas começaram a se definir como mulheres, como afirma Jade:

Eu já sabia que não era homem, nem gay afeminado, eu não queria que me chamassem de homem ou de gay, tanto é que vim só namorar com homem agora, que tenho mais de 30 anos... mas namoro desde os 16, 17 anos, antes eu me relacionava com mulheres, porque eu tinha receio de ser confundida com um gay. Se eu namorasse homem teria que ser gay também e eu não queria isso. O que me comanda é o feminino. Até hoje fico com mulheres, mas assim, não vejo nada demais nisso. Minhas amigas dizem que eu sou "sapatrans". Eu digo que sou pansexual. Meus relacionamentos com mulheres foram como se eu fosse mulher e não homem.

Nesse caso, ao se nomear como mulher embora tivesse relacionamento com outras mulheres, entede que se nomear de acordo com o seu sexo biológico, seria uma falsa identidade, porque mesmo ao relacionar com mulheres não o fez como um homem: "Ser homem é algo que não corresponde ao que eu sou".

Para Alexia as festas na época de adolescente a ajudaram a se afirmar como mulher:

As festas sempre me ajudaram, mas sempre como mulher, porque ia vestida de mulher, eu não me sentia mais como homem. Eu não estava mais me sentindo bem fingir que era homem.

A fala de Alexia mostra a transição e o abandono por comple de todos elementos de masculinidade que foram lhe impostos, para se sentir como mulher. O voleibol é o esporte que deve ser jogado; o salão de beleza é o espaço profissional que lhe foi designado, mas que o qual ela se identifica e 
se realiza como mulher enquanto trabalha e compartilha conversas com as clientes, que falam de suas vidas, amores e lhes pede sugestões e conselhos sobre roupas, sapatos e tipos de penteados. Alexia sabe que embora se sinta como mulher, nem sempre os outras tem o mesmo olhar:

"Para algumas pessoas eu continuo sendo homem, por causa de minha biologia e diferente por causa de minha identidade de gênero.

Nesse sentido, para os outros seu discurso reitera permanentemente o ininteligível: o que somos, nós somos assim, como uma raridade ou abjeção.

A história de Sheeva Star ilustra durante uma fase de sua vida, a identificação com o gay que "dá pinta", também conhecido como "Pintosa". Esta denominação foi importante enquanto ainda predominou, ao menos exteriormente, o gênero correspondente ao sexo biológico:

Eu ainda não era travesti, mas também não era apenas a bicha discreta, eu dava pinta o tempo todo, ao mesmo tempo que era muito feminina. (Sheeva Star)

O seu relato fala de uma feminilidade no sentido da delicadeza, suavidade, combinado com atitudes um pouco mais escandalosa que poderiam ser interpretados como alguém que expressa a feminilidade de forma exagerada através de gestos, do manejo do corpo e da fala, o que difere do homossexual masculinizado.

De bicha escandalosa, bem afeminada a travesti. Sim, porque eu sempre tive o cabelo crespo e meu cabelo demonstra o que sou, assim pra cima, alegre. Todo mundo sempre me olhava quando no ginásio, nos jogos de volei, quando eu jogava volei, eu era o gay escandaloso. Todo mundo me olhava assim. Dai quando me tornei já tinha 16 anos. Naquela época, eu era o famoso nos jogos de volei. Eu e uma outra a Suzy. Todos 
os demais eram gays. A gente reinava, a gente tava próxima de oganizar um reinado gay nos jogos de volei da escola. Nós tentamos isso uma idéia de fazer isso e nós estávamos organizando, então eu tive a iniciativa junto com a Gabriela. Nós temos a gravação do reinado, foi muito bom, e é aí que muitas garotas (mulheres cis) queriam participar de nosso grupo. Mas o grupo era formado principalmente por gays afeminados, mas naquela época eu já era travesti. (Sheeva Star).

Em todo esse percurso de histórias dessas mulheres na busca de negar e afirmar uma identidade de gênero chega-se em um momento em que ser travesti, homem efeminado ou gay "pintosa" não é o bastante para dizer o que são. Então, aparece nos relatos, a participação em concursos de miss ${ }^{5}$. É um momento decisivo como relatam Jade e Sheeva Star. Esses concursos se constituem em estímulos fundamentais para a transição definitiva que significa um salto entre a etapa individual para uma etapa coletiva de identificação com o mundo trans. Os concursos são espaços de gays efeminados, travestis e trans por excelência, para mostrar-se e competir para definir quem é mais bela e feminina.

\begin{abstract}
Apenas terminei o ensino médio. Não quis mais estudar. Eu não deixava crescer mais pelos e ia aos concursos, queria ser travesti. Fui a concursos em diferentes lugares. Aqui, Rondonópolis, Corumbá. O dinheiro que eu ganhava fazendo programas guardava e ia aos concursos, pagava inscrição, viagem, roupas, ia sempre como travesti. Nesses concursos aqui em Campo Grande, em que participaram várias pessoas, gays e trans e outras travestis bonitas me disseram que eu era a mais bonita, mais feminina que as outras, porém, elas tinham mais experiência e ganharam, tinham mais peito, mas não eram peitos de verdade e isso é mais de fácil de acomodar e dar uma harmonia com o resto do corpo. Mas já fiquei em segundo lugar num concurso em Rondonópolis. (Jade)
\end{abstract}

\footnotetext{
${ }^{5}$ Em Campo Grande, esses concursos de miss são realizados todos os anos, sendo organizados pelo Movimento de Estudo de Sexualidade, Cultura, Liberdade e Ativismo de Mato Grosso do Sul (MESCLA)e as participantespodem concorrer nas categorias miss gay, miss transex e miss gay plussize. Todas as participantes desfilam com roupas femininas, mas nem todas são consideradas mulheres trans.
} 
A história de Doca ${ }^{6}$, ela fala de uma suposta expressão de gênero neutra, expressão que contém seus desejos e sentimentos, mas que não é expressa na frente dos outros para não chamar atenção. A expressão de gênero neutra não mostra o gênero desejado, mas também não revela gênero atribuído no nascimento. O uso de roupas mais largas, alargadores nas orelhas, cabelos curtos podem ajudar a demonstrar essa neutralidade: nem homem, nem mulher ou, simplesmente, não-binária ${ }^{7}$. No entanto, essa expressão não é totalmente neutra, já que a diferença sempre está presente como uma marca indelével da existência dessas pessoas:

\begin{abstract}
Em outras palavras, quando terminei o ensino médio fui para a faculdade, isto é, eu tentava evitar que vissem muito além do que eu poderia ser. Quando eu estava entrando na faculdade eu estava vendo que não é um ambiente muito confortável em que eu tinha que interagir com outras pessoas e isso era desconfortável para mim. Nem tinha roupa pra isso. Eu queria ser aceito pelos meninos, mas eu nunca prestei muito atenção nas roupas que eu visto. Só visto. Mas eu queria ser visto de forma diferente pelos meninos. As vezes eu ficava animado quando algum deles me olhava de outra maneira. Isso foi só uma ilusão, nunca passou dos olhares. Nada de concreto aconteceu. As vezes eu pensava que se vestisse de menina, pudesse ser melhor, mas eu não tinha vontade e também isso já nem penso mais nisso. Eu tinha uma atitude de menino, as vezes menina certo? Quero dizer, ai eu disse que tenho que me localizar. Eu tenho que ser masculino, eu tenho que ser gay, ou mulher. Mas no fim, eu não ia mesmo esculpir isso na minha cabeça. (Doca)
\end{abstract}

Em todos os relatos aparece um profundo apego a mãe, as ocupações das mulheres e a as amigas mulheres. As trans se rodeiam do mundo feminino para aprender. O trânsito se apresenta como um processo marcado pela diferença nos traços e comportamentos manifestados no modo de ser mulher trans.

$\mathrm{Na}$ fala dessas mulheres, ser mulher é uma arte, uma dedicação exclusiva ao comportamento e a atitude, não necessariamente de fazer bem as tarefas domésticas. Ser mulher é ser feminina e no discurso delas, se opõe a ser rude, áspera e também de saber o momento de ficar quieta. Isso implica uma mudança em relação à infância. Durante a infância, a

\footnotetext{
${ }^{6}$ Nome fictício. Essa pessoa não se representa como mulher e nem como homem, embora tenha nascido com sexo masculino. Usa ainda o nome atribuído pelos pais.

${ }^{7}$ Numa noção ampla, a identidades de gênero não-binárias é uma identidade de pessoas trans que não são exclusivamente, totalmente e sempre femininos e também não são exclusivamente, totalmente e sempre masculinos.
} 
tranquilidade é uma virtude imposta, sobretudo às meninas; já na adolescência e na juventude a tranquilidade deixa de ser um valor e é preciso ter força para ser divertir, festejar, produzir e ser sexualmente ativa. A evidência da feminilidade se concentra na expectatica de que não serão confudidas com gays, especialmente diante dos homens. É sobre passar como uma mulher atraente e sedutora, escondendo os signos masculinos: a grosseria no rosto, nas feições, nas mãos ou na voz, que são os elementos que podem deixá-las descobertas. Tudo isso requer um ótimo investimento de tempo e dinheiro. Requer dedicação exclusiva para fazer desaparecer o masculino. Por exemplo, a voz deve ser modulada para que a voz do homem não saia e o cabelo comprido será uma das primeiras coisas a se fazer no processo de transformação.

\section{Considerações finais}

Os relatos até aqui analisados, demonstram que as mudanças identitárias não se fecham em identidades estáticas e unitárias, tampouco a identidade de gênero corresponde a uma essência, se trata mais de uma forma fluida de, que tem a ver com a história, a memória e as relações que as mulheres trans estabelecem ao longo de suas vidas. Podem experimentar como identidades constantes ou identidades que tem um passado com muitas marcas e resiliências.

Podem ser também identidades em processo de construção, na qual se entra e se sai em liberdade. Alguns processos construídos ao longo da vida foram ocultados em razão das sanções sociais. A trajetória de algumas dessas mulheres, enquanto jovens esconderem sua transexualidade, por não saberem como nomear ou ainda, para se proteger ou proteger o grupo familiar do preconceito e da agressão, optando por atributos ou nomeações identitárias mais conhecidas, como por exemplo, a homossexualidade. Essa atitude serviu para dissimular um gênero que aflorava, porém que ainda não lhe pertencia. Com efeito, a identidade não é monolitica e pode mudar de acordo com as circunstâncias sociais, o espaço e das interações propiciando sempre uma revisão de sua própria identidade de gênero. 
As falas das mulheres trans, são por vezes um pouco embaraçadas. O discurso se alterna entre o masculino e o feminino na hora de nomear-se. Esta situação é confusa para elas e se manifesta também na linguagem. A experiência da diferença e as posteriores transformações do corpo permitem a construção e uso de diversas formas gramaticais que fazem aflorar um discurso com novos significados na identidade de gênero. Desta forma, paralelamente à mudança de identidade, se articulam sistemas de significado produzidos por essas mulheres, que trazem à tona a nova realidade.

A palavra diferença aparece em todos os relatos, na qual a unidade de comparação é sempre a ideia que a sociedade, o grupo familiar e os amigos fazem da masculinidade, se é homem, deve se comportar como tal. Nesse aspecto, as colaboradoras se sentem diferentes aos olhos dos demais. Desta maneira, a identidade de gênero se constitui um lugar da diferença, é uma multiplicidade de possibilidades, diferenças em um permanente transformase. A diferença se manifesta no início como um enigma, tanto para elas, quanto para as pessoas que as rodeiam. O trânsito se apresenta como um processo que vai da diferença nos traços físicos e atitudes, até a manifestação de uma forma de ser mulher. Isto indica que esta identidade vinculada a diferença é uma mudança permanente contra a opressão, exclusão e a subalternidade que sufoca a autoestima, possibilitando a criação de formas de agência para sobreviver, produzir, amar, se relacionar e serem reconhecidas.

\section{Referências}

BARBIERI M. A.. Los relatos de vida de lasmujeres, Un aporte al conocimiento de la identidad social femenina. Revista Mora, UBA, Buenos Aires, No. 1. 1995.

BENTO, B. A reinvenção do corpo. Sexualidade e gênero na experiência transexual. Rio de Janeiro: Garamond. 2006.

BOSI, E. Memória e Sociedade: Lembranças de velhos, 10ed. São Paulo: Cia das Letras, 1995. 
BUTLER, J. Corpos que pesam: sobre os limites discursivos do sexo. In: LOURO, Guacira Lopes. O Corpo Educado: Pedagogias da sexualidade. Belo Horizonte: Autêntica. 2007.

Problemas de gênero. Feminismo e subversão da identidade. Rio de Janeiro: Civilização Brasileira, 2010.

DERRIDA, J. La différance. In: Buletin de La Societé Française de Philosophie. Paris, julho-setembro, 1968.

FACIOLI, L.; MISKOLCI, R. Conectadas: experiência de subalternidade e ajuda mútua feminina online entre mulheres de classes populares. In: Mediações, Londrina, v. 20 n. 2, jul./dez. 2015

FOUCAULT, M.. História da Sexualidade. Vontade de saber. Rio de Janeiro: Graal, 1984.

GROSSBERG, L. Identidad y estúdios culturales: ¿no hay nada más que eso? Cuestiones de Identidad Cultural. Buenos Aires: Amorrortu. 1996.

HALL, S. A identidade Cultural na pós-modernidade. Rio de Janeiro: Lamparina, 2014.

KING, D. Confusiones de género: Concepciones psicológicas y psiquiátricas sobre e ltrasvestismo y la transexualidad. In: NIETO, J. A. (org). Transexualidad, transgenderismo y cultura: Antropologia, identidad y género. Madrid: Talasa, 1998.

LOURO, G. L. Um corpo estranho: ensaios sobre sexualidade e teoria queer. Belo Horizonte: Autêntica, 2004.

LLAMAS, R. Teoria torcida: Prejuicios y discursos en torno a la "homosexualidad». Madrid: Siglo XXI, 1998.

RUBIN, G. Deviations: A Gayle Rubin Reader. Durham, North Carolina: Duke University Press, 2012.

SCOTT, J. La Citoyenne Paradoxale: Les feminists française set les droits de lê homme. Paris: Ed. Albin Michel, 1998. 